Part of Journal of Research of the National Bureau of Standards, Volume 17, July 1936

\title{
SOLUBILITY OF CALCIUM 2-METHYLBUTYRATE IN WATER
}

\author{
By David F. Houston
}

\section{ABSTRACT}

This paper presents new data for the solubility of calcium 2-methylbutyrate in water from 0 to $100^{\circ} \mathrm{C}$. Earlier information concerning the solubility and hydration of this salt is compared with the present results. A transition from the pentahydrate to the hemihydrate is found to occur at $36.5^{\circ} \mathrm{C}$, at which temperature the solubility reaches a maximum value of $29.90 \mathrm{~g}$ of anhydrous salt per $100 \mathrm{~g}$ of water. The solubility rises to this maximum from $23.05 \mathrm{~g}$ of anhydrous salt per $100 \mathrm{~g}$ of water at $0^{\circ} \mathrm{C}$, and then decreases to a value of $19.80 \mathrm{~g}$ of anhydrous salt per $100 \mathrm{~g}$ of water at $100^{\circ} \mathrm{C}$.

\section{CONTENTS}

I. Introduction

II. Materials

III. Solubility

IV. Hydration

V. References_........ 58

\section{INTRODUCTION}

Definite information concerning the solubility and the hydration of calcium 2-methylbutyrate was desired in the course of an investigation at this Bureau of some salts of the fatty acids. A survey of the literature disclosed the fact that the existing information was confusing and apparently in error, and indicated the desirability of a redetermination of these properties.

In 1887 Sedlitzky [1] $]^{1}$ determined the solubilities of the calcium salts of 2-methylbutyric, isovaleric, and isobutyric acids. In the same year, Krasnicki [2] determined the solubilities of the calcium and barium salts of formic, acetic, and propionic acids. The results of both investigators give curves which are, in some cases, concave to the temperature axis of the temperature-concentration diagram. The results of later investigators [3] show solubility curves of fattyacid salts which are all convex to the temperature axis, and these authors point out that the data of the earlier investigators are often in error. The values obtained by Sedlitzky for the solubility of calcium 2-methylbutyrate ${ }^{2}$ in water over the range from 0 to $80^{\circ} \mathrm{C}$ are the only ones available for this salt. The curve expressing these data is strongly concave to the temperature axis, and thus appears

\footnotetext{
1 Figures in brackets here and elsewhere in the text relate to the reference numbers given at the end of this paper.

${ }_{2}^{2}$ Unless otherwise indicated, all references to the acid and its salt in this paper are to the $d l$ - or inactive form.
} 
to be incorrect. A new determination of the solubility over the range from 0 to $100^{\circ} \mathrm{C}$ is presented in this paper.

According to Milojković [4], the salt exists in three different forms at different temperatures: a pentahydrate at $0^{\circ} \mathrm{C}$, a trihydrate at 23 to $26^{\circ} \mathrm{C}$, and a monohydrate at 85 to $90^{\circ} \mathrm{C}$. Other authors [5] who have dealt with this salt refer only to the pentahydrate. The results of the present investigation serve to remove the existing confusion concerning the hydration of the salt.

\section{MATERIALS}

Secondary butyl bromide was prepared [6] from secondary butyl alcohol, ${ }^{3}$ and fractionated to give a product boiling at $91.3 \pm 0.1^{\circ} \mathrm{C}$ at $760 \mathrm{~mm}$. From this bromide, 2-methylbutyric acid was formed through the Grignard reaction according to the procedure given in Organic Syntheses [7]. A fraction boiling at 174 to $177^{\circ} \mathrm{C}$ at $757 \mathrm{~mm}$ was collected and treated in aqueous solution with a slight excess of calcium carbonate containing $\angle 0.005$ percent of barium and $\angle 0.001$ percent of heavy metals as lead. The solution was refluxed to complete the reaction and was filtered from residual solids. It was extracted with ether to remove any unreacted acid, and the salt was fractionally crystallized. Samples of each fraction were dried at $105^{\circ} \mathrm{C}$, and calcium was determined in the anhydrous material by treating it in aqueous solution with dilute sulfuric acid, evaporating, driving off the excess acid, and igniting the $\mathrm{CaSO}_{4}$ formed.

$\mathrm{Ca}$ (theory for anhydrous salt) 16.54 percent.

$\mathrm{Ca}$ (found in fractions dried at $105^{\circ}$ C) $16.52,16.24,16.46,16.51$, $16.48,16.43,16.43,16.43$, and 16.48 percent.

\section{SOLUBILITY}

The apparatus and procedure for determining the solubility of the salt have been described in detail in a previous article [3e]. In brief, the apparatus was such that filtering was done in the body of the solution, and samples were filtered by pressure rather than by suction, to avoid loss of solvent. The solubility at $0^{\circ} \mathrm{C}$ was determined in a bath of melting ice. At all other temperatures the constanttemperature bath previously described was used. The weight of anhydrous salt in a known weight of saturated solution was determined by evaporation of the solution to a residue of constant weight at $105^{\circ} \mathrm{C}$. The results were calculated to the weight of anhydrous salt per $100 \mathrm{~g}$ of water. The values obtained by this method are in complete agreement on duplicate samples with those gotten by determining the amount of calcium as calcium sulfate, and calculating from it the quantity of anhydrous salt.

The results of the solubility determinations are shown in figure 1 by the solid curve drawn through the experimental points. Each point is the average of duplicate determinations. For ready comparison, the data of Sedlitzky are represented by a dotted line in the same figure. The solubilities at 10-degree intervals and at the transition point, taken from the curve expressing the present results, are shown below.

${ }^{3}$ Stanco Distributors, New York, N. Y., kindly supplied a quantity of this alcohol. Their assistance is gratefully acknowledged. 


\begin{tabular}{|c|c|c|c|c|c|c|c|c|c|c|c|c|}
\hline Temperature, in ${ }^{\circ} \mathrm{C}$ & 0 & . 10 & 20 & 30 & 36.5 & 40 & 50 & 60 & 70 & 80 & 90 & 100 \\
\hline $\begin{array}{l}\text { Grams of anhydrous salt } \\
\text { per } 100 \mathrm{~g} \text { of water }\end{array}$ & 23.05 & 23.60 & 24.55 & 27.15 & 29.90 & 29.10 & 26.60 & 24.45 & 22.80 & 21.40 & 20.35 & 19.80 \\
\hline
\end{tabular}

Duplicate samples usually checked within $0.05 \mathrm{~g}$ of anhydrous salt per $100 \mathrm{~g}$ of water, and determinations approaching equilibrium at any one temperature from saturation conditions at higher and lower temperatures located the desired points within $0.1 \mathrm{~g}$ of anhydrous salt per $100 \mathrm{~g}$ of water. This is considered to be the accuracy herein obtained.

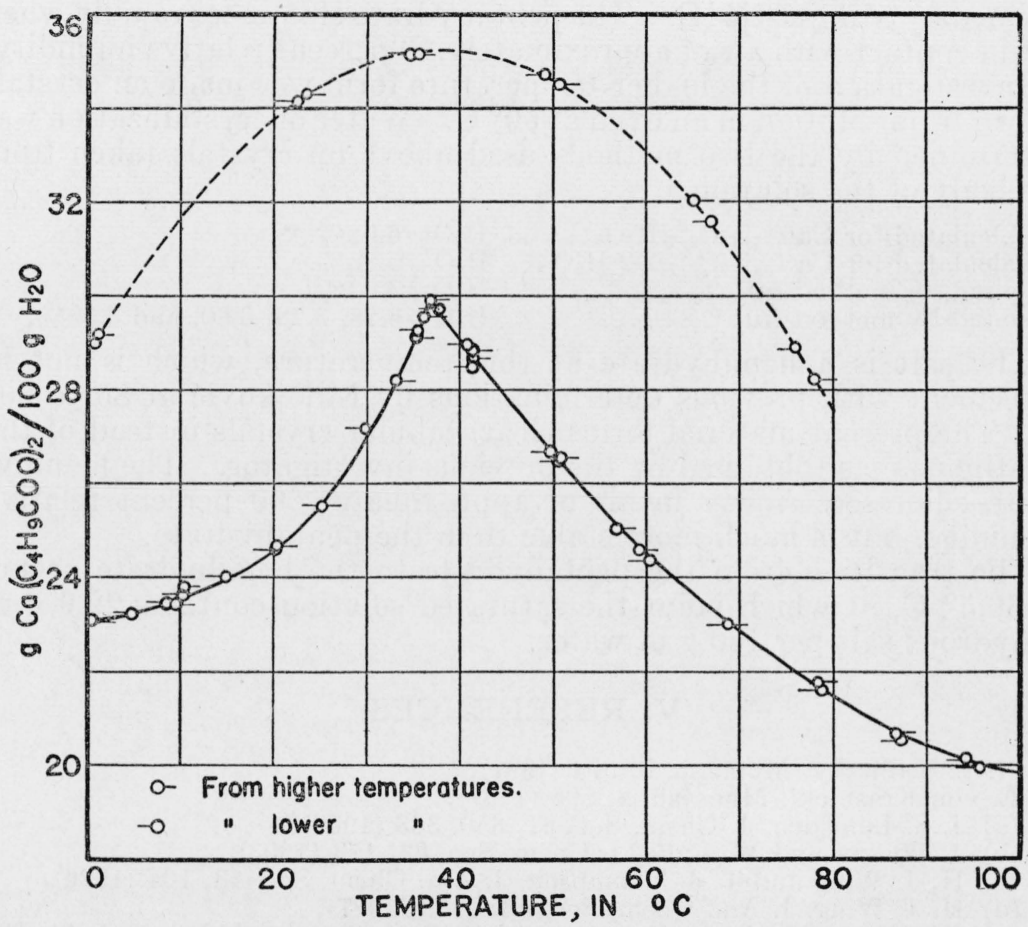

FIgURE 1.-Solubility of calcium 2-methylbutyrate in water.

\section{HYDRATION}

It is evident from the solubility curve that only two forms of the salt exist in equilibrium with saturated solutions in the temperature range from 0 to $100^{\circ} \mathrm{C}$. Moreover, microscopical examination ${ }^{4}$ indicates that the same crystal form is obtained from solution at 0,8 , and $25^{\circ} \mathrm{C}$. These data show that there can not be two different hydrates in stable equilibrium with saturated solutions at temperatures between $36.5^{\circ} \mathrm{C}$ and $0^{\circ} \mathrm{C}$.

Crystals were grown from solution in a desiccator over sulfuric acid at room temperature (approx. $25^{\circ} \mathrm{C}$ ), and water of crystalliza-

1 Microscopical examination was made by C. P. Saylor. 
tion was determined on crystals taken from the body of the solution. They were dried in one of two ways: (a) by pressing them between filter paper, and (b) by centrifugal filtration, using an apparatus [8] devised during this investigation. The water of crystallization was then determined by heating to constant weight at $105^{\circ} \mathrm{C}$. The results are in agreement for both methods of drying.

Calculated for $\mathrm{Ca}\left(\mathrm{C}_{5} \mathrm{H}_{9} \mathrm{O}_{2}\right)_{2} .5 \mathrm{H}_{2} \mathrm{O} \ldots \ldots \ldots-\mathrm{H}_{2} \mathrm{O}=27.11$ percent Calculated for $\mathrm{Ca}\left(\mathrm{C}_{5} \mathrm{H}_{9} \mathrm{O}_{2}\right)_{2} \cdot 4 \frac{1}{2} \mathrm{H}_{2} \mathrm{O} \ldots \ldots . \ldots \mathrm{H}_{2} \mathrm{O}=25.08$ percent

Calculated for $\mathrm{Ca}\left(\mathrm{C}_{5} \mathrm{H}_{9} \mathrm{O}_{2}\right)_{2} \cdot 3 \mathrm{H}_{2} \mathrm{O} \ldots$ Found by method (a) Found by method (b)

These values agree with those of previous investigators [5] who found the pentahydrate, but offer no confirmation of the trihydrate claimed by Milojković [4]. The pentahydrate effloresces rapidly when left in contact with air of approximately 60 percent relative humidity.

Investigation of the higher-temperature form was made on crystals grown from solution in an oven at $60^{\circ} \mathrm{C}$. Water of crystallization was determined by the two methods used above on crystals taken from the body of the solution.

Calculated for $\mathrm{Ca}\left(\mathrm{C}_{5} \mathrm{H}_{9} \mathrm{O}_{2}\right)_{2} \cdot \mathrm{H}_{2} \mathrm{O} \ldots \ldots \mathrm{H}_{2} \mathrm{O}=6.92 \%$.

Calculated for $\mathrm{Ca}\left(\mathrm{C}_{5} \mathrm{H}_{9} \mathrm{O}_{2}\right)_{2} \cdot 1 / 2 \mathrm{H}_{2} \mathrm{O}_{-1} \mathrm{H}_{2} \mathrm{O}=3.86 \%$.

Found by method (a) ........ $\mathrm{H}_{2} \mathrm{O}=3.63 \%$.

Found by method (b) .............

The salt is a hemihydrate at this temperature, which is not in agreement with previous determinations by Milojković at 85 to $90^{\circ}$ C. The present material forms clear, tabular crystals instead of the gelatinous mass obtained by the previous investigator. The hemihydrate effloresces slowly in air of approximately 60 percent relative humidity, but is much more stable than the pentahydrate.

The transition from the pentahydrate to the hemihydrate occurs at $36.5^{\circ} \mathrm{C}$, at which point the saturated solution contains $29.9 \mathrm{~g}$ of anhydrous salt per $100 \mathrm{~g}$ of water.

\section{REFERENCES}

[1] N. L. Sedlitzky, Monatsh. 8, 573 (1887).

[2] E. von Krasnicki, Monatsh. 8, 595 (1887).

[3] (a) J. S. Lumsden, J. Chem. Soc. 81, 350, 363 (1902).

(b) J. Walker and W. Fyffe, J. Chem. Soc. 83, 173 (1903).

(c) H. J. Wing and T. J. Thompson, J. Am. Chem. Soc. 48, 104 (1926).

(d) H. J. Wing, J. Am. Chem. Soc. 49, 2859 (1927).

(e) F. W. Ashton, D. F. Houston and C. P. Saylor, BS J. Research 11, 233 (1933) RP587.

[4] D. Milojković, Monatsh. 14, 702 (1893).

[5] (a) A. Pagenstecher, Liebig's Ann. 195, 119 (1879).

(b) M. Conrad and C. A. Bischoff, Liebig's Ann. 204, 152 (1880).

(c) E. Schmidt, Liebig's Ann. 208, 258 (1881).

(d) N. L. Sedlitzky, reference [1] of this paper.

(e) H. Taverne, Rec. trav. chim. 13, 197 (1894). (Salt of $d$-acid.)

(f) O. Schutz and W. Marckwald, Ber. deut. chem. Ges. 29, 52 (1896). (Salt of $l$-acid.)

[6] D. F. Houston, J. Am. Chem. Soc. 55, 4131 (1933).

[7] Organic Syntheses 5, 75-77 (J. Wiley \& Sons, New York, N. Y., 1925.)

[8] D. F. Houston and C. P. Saylor, Ind. Eng. Chem., Anal. Ed. 8, (July 15, 1936).

Washington, April 27, 1936. 